\title{
\#397
}

\section{INHIBITORY EFFECTS OF QUINIDINE ON RAT HEART MUSCARINIC RECEPTORS}

M. Waelbroeck, P. De Neef, P. Robberecht and J. Christophe

Department of Biochemistry and Nutrition, Medical School, Université Libre de Bruxelles, Bld. de Waterloo 115 , B-1000 Brussels, Belgium.

(Received in final form July 3, 1984)

\section{Sumary}

Quinidine inhibited binding of the labelled agonist $\left[{ }^{3} \mathrm{H}\right]$ oxotremorine $\mathrm{M}([3 \mathrm{H}] \mathrm{O} \times \mathrm{O}-\mathrm{N})$ and the labelled antagonist $[3 \mathrm{H}] \mathrm{N}$-methylscopolamine ([3H]NMS) to rat heart muscarinic receptors. Kinetic studies demonstrated that quinidine decreased the association rates ( $I_{50}: 4$ and $7.5 \mu \mathrm{M}$ ) and dissociation rates ( $\mathrm{I}_{50}: 100$ and $68 \mu \mathrm{M}$ ) of $[3 \mathrm{H}] 0 \times \mathrm{O}-\mathrm{M}$ and $[3 \mathrm{H}] \mathrm{NMS}$, with different potencies. These cooperative effects explained the low Hill coefficients and apparent selectivity of quinidine competition curves.

Quinidine is a widely used antiarrythmic drug. It decreases membrane conductivity and increases the refractory period in the heart. At therapeutic concentration, it may induce cardioaccelerating effects whereas at toxic concentration it reduces the cardiomoderator effects of vagal stimulation [1]. Depending on the adrenergic tone quinidine effects on isolated guinea pig atria have been described as anticholinergic [2] or not anticholinergic [1]. "Functional" antagonism is quite possible since, as acetylcholine, quinidine influences both potassium and calcium currents [3]. It is therefore difficult to interpret these data in terms of "atropine-like" effects only. In vitro studies [4] have shown that quinidine competes with $\left[{ }^{3} \mathrm{H}\right]$ quinucl idinylbenzilate (a muscarinic antagonist) for binding to rabbit heart muscarinic receptors at "therapeutic" concentration. In this work, we further characterized the interactions of quinidine with cardiac muscarinic receptors by studying the effects of this drug on the binding kinetics of the muscarinic agonist [ $3 \mathrm{H}]$ oxotrenorine $\mathrm{M}$ and the muscarinic antagonist $\left[{ }^{3} \mathrm{H}\right] \mathrm{N}$-methylscopolamine.

\section{Materials and methods}

Chemicals.

$\left[\mathrm{N}\right.$-methyl $\left.-{ }^{3} \mathrm{H}\right] \mathrm{N}$-methyl scopolamine chloride $\left(\left[^{3} \mathrm{H}\right] \mathrm{NMS}\right):$ specific radioactivity $54 \mathrm{Ci} / \mathrm{mmol}$ ) and [methyl-3 $\mathrm{H}]$ oxotremorine $\mathrm{M}$ acetate ([3 $\mathrm{H}]$ 0 0 o $-\mathrm{M}$ : specific radioactivity $84 \mathrm{Ci} / \mathrm{mmol}$ ) were obtained from New England Nuclear Corporation (Dreieich, F.R.G.). Quinidine HCl was purchased from Sigma Chemical Company (St. Louis, MO, U.S.A.).

Methods

1) Preparation of rat cardiac membranes.

Rat cardiac membranes were prepared according to the method of Snyder and Drumond [5] with a few modifications, as indicated in [6]. Proteins were measured according to Lowry et al. [7]. 
2) Measurement of specific tracer binding.

$0.1 \mathrm{mg}$ of cardiac membrane proteins per ml were incubated in $1.2 \mathrm{ml}$ of $50 \mathrm{mM}$ sodium phosphate buffer ( $\mathrm{pH} 7.4)$ enriched with $1 \%$ of bovine serum albumin and $2 \mathrm{mM} \mathrm{MgCl}{ }_{2}$, and a fixed concentration of [3 $\mathrm{H}$ ] NMS (1.0 nM) or $[3 \mathrm{H}]$ 0xo-M (1.5 nM) (unless otherwise indicated), and in the presence or absence of unlabelled drug. To measure specific binding, the samples were filtered on glass-fiber filters (GF/C Whatman. Maidstone, England) and rinsed 4 times with $2 \mathrm{ml}$ of ice-cold $20 \mathrm{mM} \mathrm{Tris-HCl} \mathrm{(pH} \mathrm{7.5)} \mathrm{enriched} \mathrm{with} 0.25 \mathrm{M}$ sucrose, $2 \mathrm{mM}$ dithiothreitol, and $1 \%$ bovine serum albumin. Specific binding was defined as the difference between tracer binding in the absence and in presence of 1 ul atropine. All measurements were performed in duplicate.

2.a) Competition curves: The membranes were incubated as explained above, in the absence or presence of the indicated concentrations of atropine or quinidine for $10 \mathrm{~min}$ at $25^{\circ} \mathrm{C}$, then filtered.

2.b) Dissociation rates $\left(k_{o f f}\right)$ : The membranes were preincubated as explained above (with the tracer and 0 or $1 \mathrm{M}$ atropine) for $10 \mathrm{~min}$ at $25^{\circ} \mathrm{C}$, in a total volume of $1080 \mu \mathrm{l}, 120 \mu \mathrm{l}$ of water, atropine or quinidine and atropine were then added to each tube. Specific binding was measured by filtration at appropriate time intervals. The final concentrations of atropine and quinidine are indicated in legends of figs. 3-4. The dissociation rate constant and initial binding $B_{0}$ were calculated by linear regression analysis of $1 n$ B as a function of time ( $B$ representing specific binding) (correlation coefficients $r=0.9$ ). The initial binding $B_{0}$ calculated by this method was within $5 \%$ of "control" binding observed after addition of water.

2.c) Association rates $\left(k_{0}\right)$ : The membranes were incubated as explained above in the presence or absence of $1 \mu \mathrm{M}$ atropine or $10 \mu \mathrm{M}$ quinidine. Specific binding was measured by filtration after the indicated time intervals. The association kinetics were analyzed according to equation (1) assuming that variation of the tracer concentration was negligible [8]:

$$
\ln \frac{B_{e q}}{B_{e q}{ }^{-B} t}=\left(k_{o b s}\right) t
$$

where $\mathrm{Bt}=$ specific binding at a given time

Beq $=$ specific binding at equilibrium

$k_{\text {obs }}=k_{\text {on }} \times L+k_{\text {off }}$, where $k_{\text {on }}=$ association rate constant;

$\mathrm{L}=$ tracer concentration; $k_{\text {off }}=$ dissociation rate constant.

The "kon" values calculated by this method were in good agreement with "kon" values calculated using experimental values of $k_{0}$ ff and $\mathrm{KD}$ $\left(k_{o n}=k_{o f f} / K_{D}\right)$ for both tracers (not shown).

\section{Results}

\section{Competitivity.}

Higher quinidine concentrations were required to inhibit $\left[{ }^{3} \mathrm{H}\right.$ ] NMS binding when using increasing tracer concentrations (Fig. 1, upper panel). This suggested competitive inhibition and was further documented by : $1 /$ the fact that quinidine (up to $300 \mu \mathrm{M}$ ) decreased the apparent affinity of $[3 \mathrm{H}]$ NMS without affecting the total number of muscarinic receptors (not shown) and $2 /$ the fact that the 150 of quinidine increased linearly with [ ${ }^{3} \mathrm{H}$ ] NMS concentration (true $K_{I}$ of quinidine: 8 uM [9]) (Fig. 1, lower panel).

\section{Selectivity.}

We have previously shown that $\left[{ }^{3} \mathrm{H}\right]$ 0xo-M (a labelled agonist) binds selectively to the muscarinic receptor subclass with highest affinity for agonists in rat heart membranes whereas antagonists, such as [3H] NMS or atropine, recognize all muscarinic receptors with the same, high affinity [6]. The comparison of inhibition curves of [3H] NMS and [3 $\mathrm{H}] \mathrm{O} \times \mathrm{O}-\mathrm{M}$, therefore, allows a demonstration of drug selectivity for one of the two cardiac 
myscarinic receptors or receptor states. As shown in Fig. 2, atropine inhibits $[3 \mathrm{H}]$ oxo-M and $[3 \mathrm{H}]$ NMS binding at the same concentrations $\left(I_{50}=3 \mathrm{nM}\right.$ ) and with Hill coefficients not significantly different from 1.0 . By contrast, quinidine was a more potent inhibitor of $[3 \mathrm{H}] \mathrm{O} \times 0-\mathrm{M}\left(\mathrm{I}_{50}=8.5 \pm 0.5 \mu \mathrm{M}\right.$ and Hill coefficient of $0.70 \pm 0.02$ ) than [ $3 \mathrm{H}$ ] NMS binding ( $\mathrm{I}_{50} 22 \pm 2$ MM and $\mathrm{Hill}$ coefficient of $0.89+0.06)$. The concentrations of tracers used in this experiment were equipotent (close to their respective $K_{D}$ values) [9].

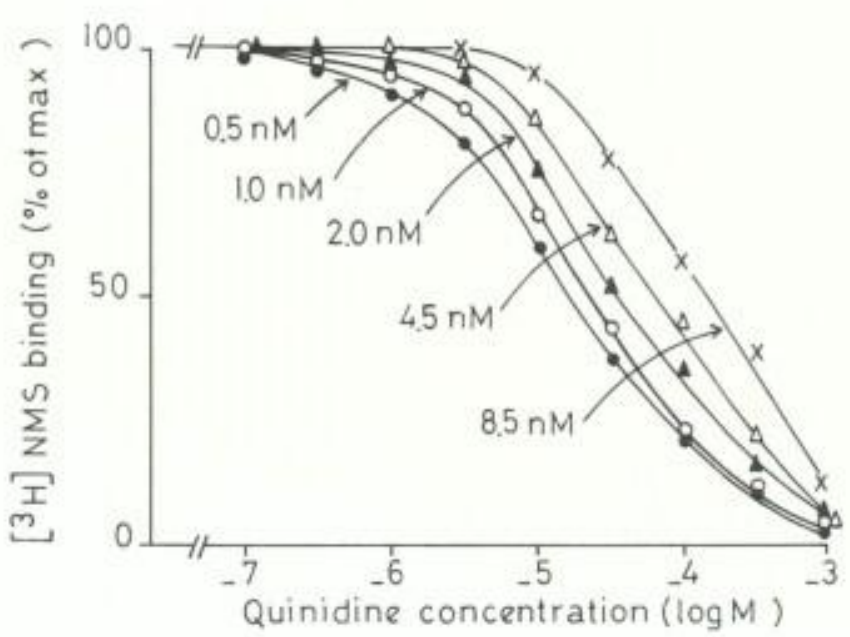

FIG. 1

Competitivity of quinidine and $\left[{ }^{3} \mathrm{H}\right]$ NMS interactions with rat heart muscarinic receptors.

Upper panel : competition curves of quinidine were measured at different $\left[{ }^{3} \mathrm{H}\right]$ NMS concentrations ( $\bullet: 0.5$; $0: 1.0 ; \triangle: 2.0$; $\triangle: 4.5$, and $x$ : $8.5 \mathrm{nM})(n=2$ experiments).

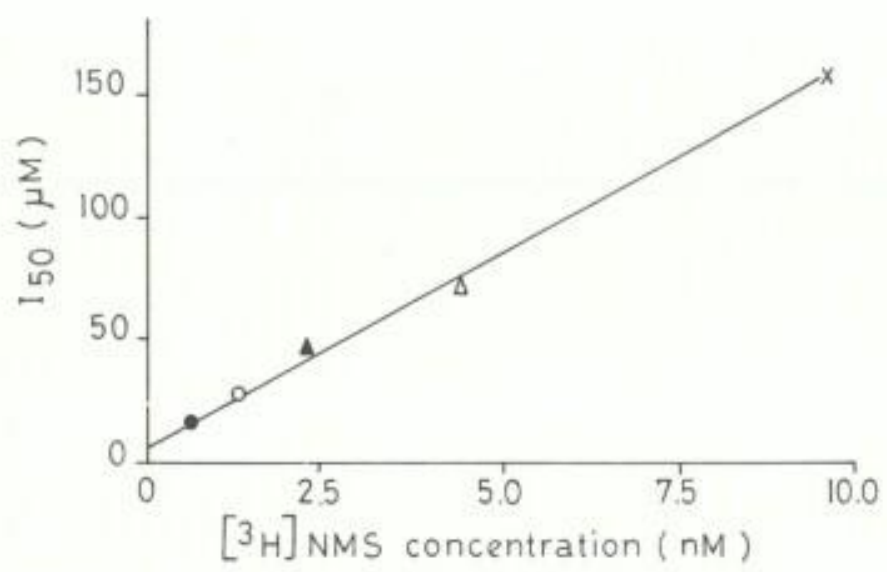

Lower panel : the concentrations of quinidine necessary to inhibit $50 \%$ of tracer binding ( ${ }_{50}$ ) were plotted as a function of [3H] NMS concentration. The KD of [3H] NMS (in the absence of quinidine) was $1.24 \pm 0.25 \mathrm{nM}$.

\section{Dissociation rate constants $\left(\mathrm{k}_{\text {off }}\right)$ of $\left[{ }^{3} \mathrm{H}\right]$ NMS and $\left[{ }^{3} \mathrm{H}\right]$ OxO-M.}

$\left[{ }^{3} \mathrm{H}\right]$ NMS and $\left[{ }^{3} \mathrm{H}\right]$ Oxo-M dissociated rapidly from muscarinic receptors, as shown on Fig. 3. The dissociation rates were first order, suggesting that both tracers recognized a kinetically homogeneous population of receptors. Quinidine $(100 \mu \mathrm{M})$, added simultaneously with a concentration of atropine (1 $\mu \mathrm{M})$ sufficient to prevent tracer reassociation, was able to decrease the k off of [3H] $\mathrm{NHS}$ and [ $3 \mathrm{H}] \mathrm{O}$ - $\mathrm{O}-\mathrm{N}$. This indicated that quinidine influenced occupied muscarinic receptors. 


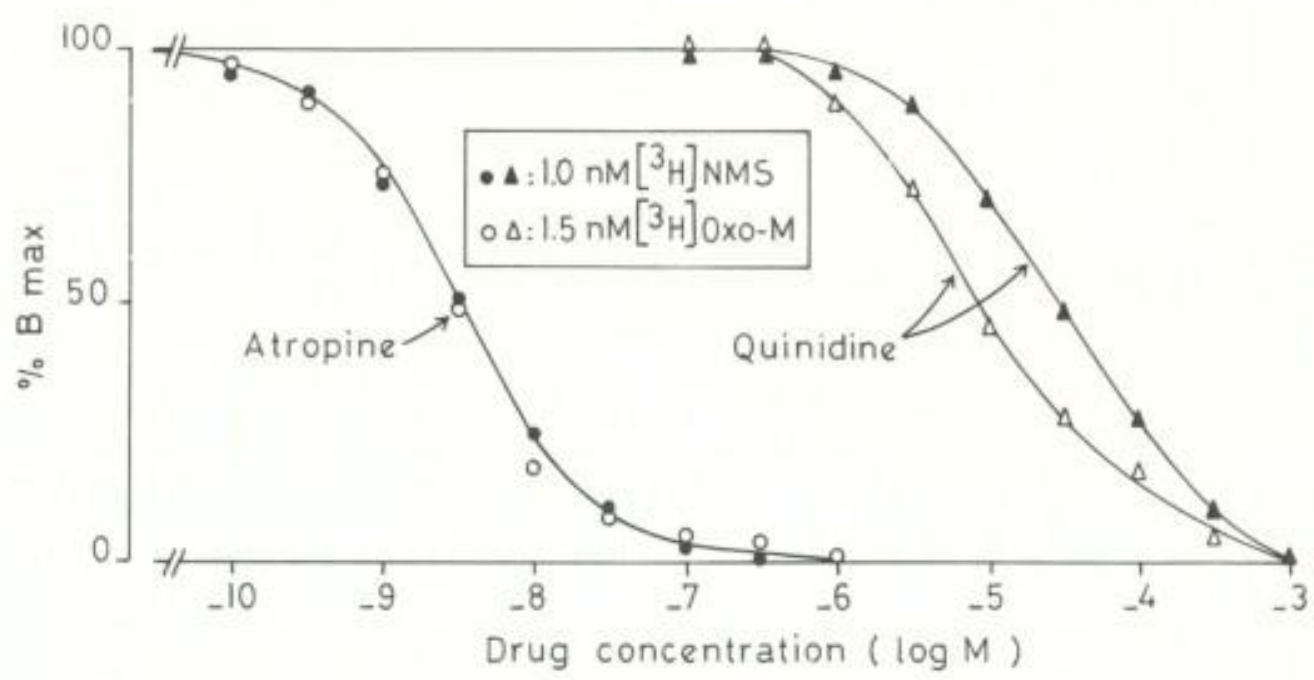

FIG. 2

Competition curves of quinidine $(\Delta, \Delta)$ and atropine $(\bullet, 0)$ with $1.0 \mathrm{nM}[3 \mathrm{H}] \mathrm{NMS}$ (closed symbols) and $1.5 \mathrm{nM}[3 \mathrm{H}]$ Oxo-M (open symbols). The results were expressed as percent of specific tracer binding in the absence of quinidine. This experiment is representative of 2 others.

\section{Dose-effect curves for dissociation kinetics.}

To measure the extent of the decrease of the $k_{\text {off }}$ value at different quinidine concentrations, tracer binding was measured after a $5 \mathrm{~min}$ isotopic dilution, in the presence of atropine $(1 \mu \mathrm{M})$ and quinidine $(0$ to $1 \mathrm{mM})$. The curve obtained (Fig. 4) was fitted according to equation (2), assuming that the binding of quinidine to a homogeneous class of binding sites was able to inhibit completely the tracer dissociation :

$$
\left(k_{\text {off }}\right)_{Q}=\frac{k_{\text {off }}}{1+\frac{Q}{K_{Q}}}
$$

where (koff) $Q$ is the dissociation rate observed in the presence of quinidine, $Q$ is the quinidine concentration and $K_{0}$ is the dissociation constant of quinidine for its binding site, when muscarinic receptors are occupied by $[3 \mathrm{H}] \mathrm{NMS}$ or $[3 \mathrm{H}] \mathrm{O} \times \mathrm{x}_{0}-\mathrm{M}$. The values of $\mathrm{K}_{0}$ were, respectively, 68 and $100 \mu \mathrm{M}$ when $[3 \mathrm{H}]$ NMS and $[3 \mathrm{H}]$ Oxo-M were used as muscarinic ligands (Table $\mathrm{I}$ ).

\section{Table I}

Apparent "dissociation constants" $K_{Q}$ and $K_{\mathcal{O}}$ of quinidine for the decrease of the dissociation and association rates of [ $\left.{ }^{3} \mathrm{H}\right]$ NMS and $[3 \mathrm{H}] \mathrm{O} \times \mathrm{OO}-\mathrm{M}($ in $\mu \mathrm{M})$. Ligand $\left[{ }^{3} \mathrm{H}\right]$ NMS $\left[{ }^{3} \mathrm{H}\right]$ OxO-M

\begin{tabular}{lrr}
\hline$K_{Q}$ for dissociation rates & $68{ }_{\mu} \mathrm{M}(58-85)$ & $100 \mu \mathrm{M}(63-158)$ \\
$\mathrm{K}_{Q}^{\prime}$ for association rates & $7.5{ }_{\mu} \mathrm{M}(6.5-8.5)$ & $4 \mu \mathrm{M}(3.5-4.5)$
\end{tabular}

(The values of $K_{Q}$ and $K^{\prime} Q$ were fitted as explained in legend of Fig. 4; the values given in parentheses give a significantly worse fit of the experimental data shown in Figs. 1 and 4 ). 


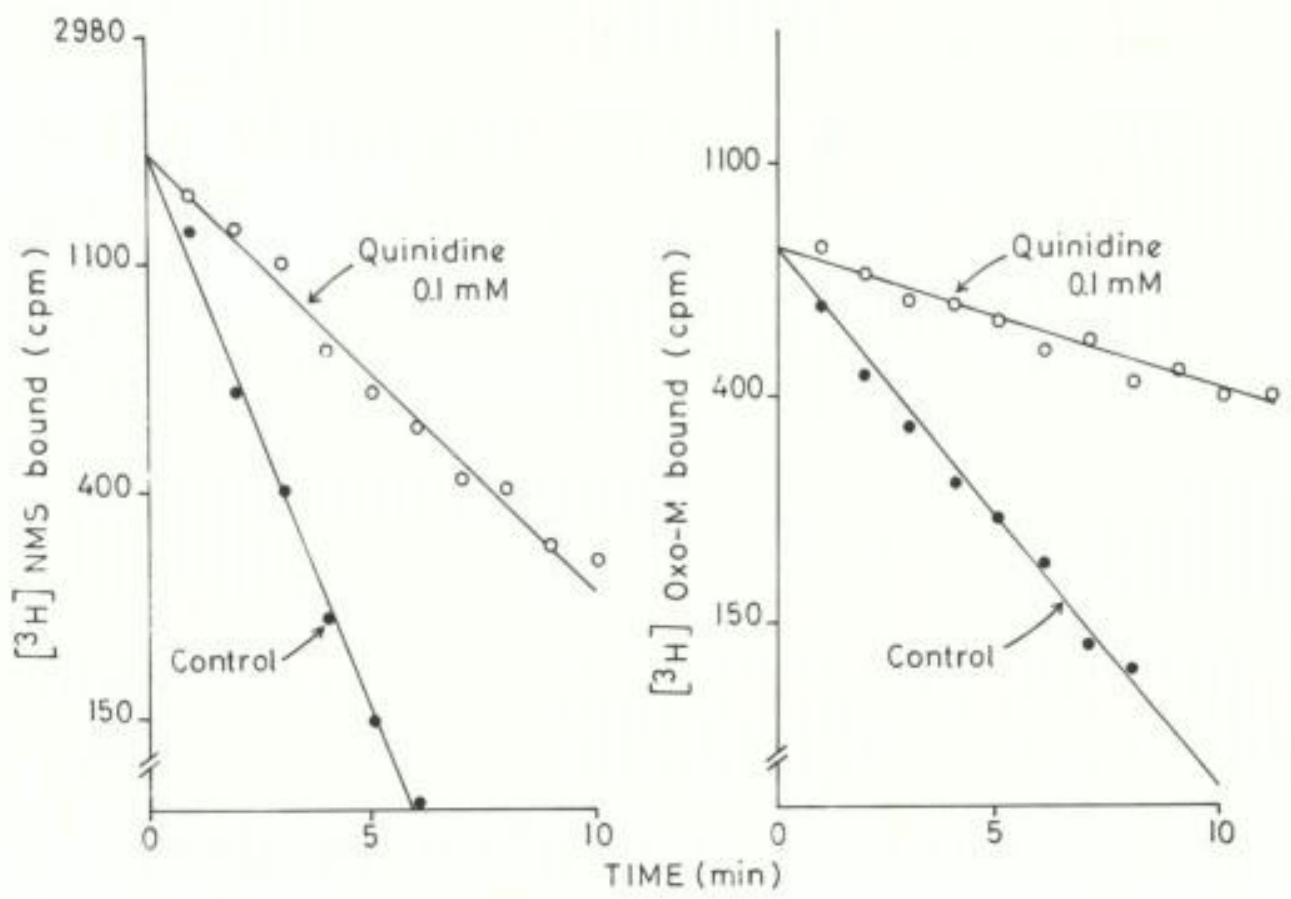

FIG. 3

Dissociation kinetics of $\left[{ }^{3} \mathrm{H}\right]$ NMS (left panel) and $\left[{ }^{3} \mathrm{H}\right]$ 0xo-M (right panel) induced by addition at time zero of atropine alone $(1 \mu \mathrm{M})(\bullet)$ or atropine $(1 \mu \mathrm{M})$ and quinidine $(100 \mu \mathrm{M})(0)$. This experiment is representative of 2 others.

\section{Association rate of $\left[{ }^{3} \mathrm{H}\right]$ NMS and $\left[{ }^{3} \mathrm{H}\right] 0 \times 0-\mathrm{N}$.}

The association kinetics of a labelled drug in the presence of a competing unlabelled drug may be difficult to interpret if the dissociation rates of both drugs are similar [10]. This was apparently not the case here as quinidine decreased markedly, and almost immediately, the apparent "kobs" values of $[3 \mathrm{H}]$ NMS and $\left[{ }^{3} \mathrm{H}\right]$ OxO-M (Figs. 5 and 6 ), suggesting that quinidine equilibrated very rapidly with muscarinic receptors. We therefore calculated the apparent association rates of $\left[{ }^{3} \mathrm{H}\right]$ NMS and $[3 \mathrm{H}]$ 0xo-M (Fig. 4 ) according to Tolkovsky [8]:

$$
\begin{aligned}
& B_{t}=B_{e q} e^{-\left(k_{o n} L /\left(1+Q / K^{\prime}{ }_{Q}\right)+\left(k_{\text {off }}\right)_{Q}\right) t} \\
& \text { With } B_{e q}=\frac{R_{T} L}{L+K_{L}}=\frac{k_{\text {on }} R_{0} L}{k_{\text {off }}}
\end{aligned}
$$

where $K^{\prime} Q$ is the dissociation constant of quinidine for the binding sites affecting the muscarinic 1 igand association rate, $R_{T}$ is the total receptor concentration and $R_{0}$ is the free receptor concentration.

and $K_{L}=\frac{k_{\text {off }}}{k_{\text {on }}}=\frac{k_{\text {off }}}{k_{\text {on }} /\left(1+Q / K_{Q}^{\prime}\right)}$ is the apparent $K_{D}$ of the tracer- 
receptor complex in the presence of quinidine. Quinidine was apparently able to block completely [ $\left.{ }^{3} \mathrm{H}\right]$ NMS and $\left[{ }^{3} \mathrm{H}\right]$ 0xo-M binding, through an interaction with a homogeneous class of binding sites (Table I). The competition curves obtained after a $10 \mathrm{~min}$ incubation were compared to theoretical curves (dashed lines) calculated using equation (3) and the fitted values of $K_{Q}$ and $K_{Q}^{\prime}{ }_{Q}$ (Table I) in Fig. 4.
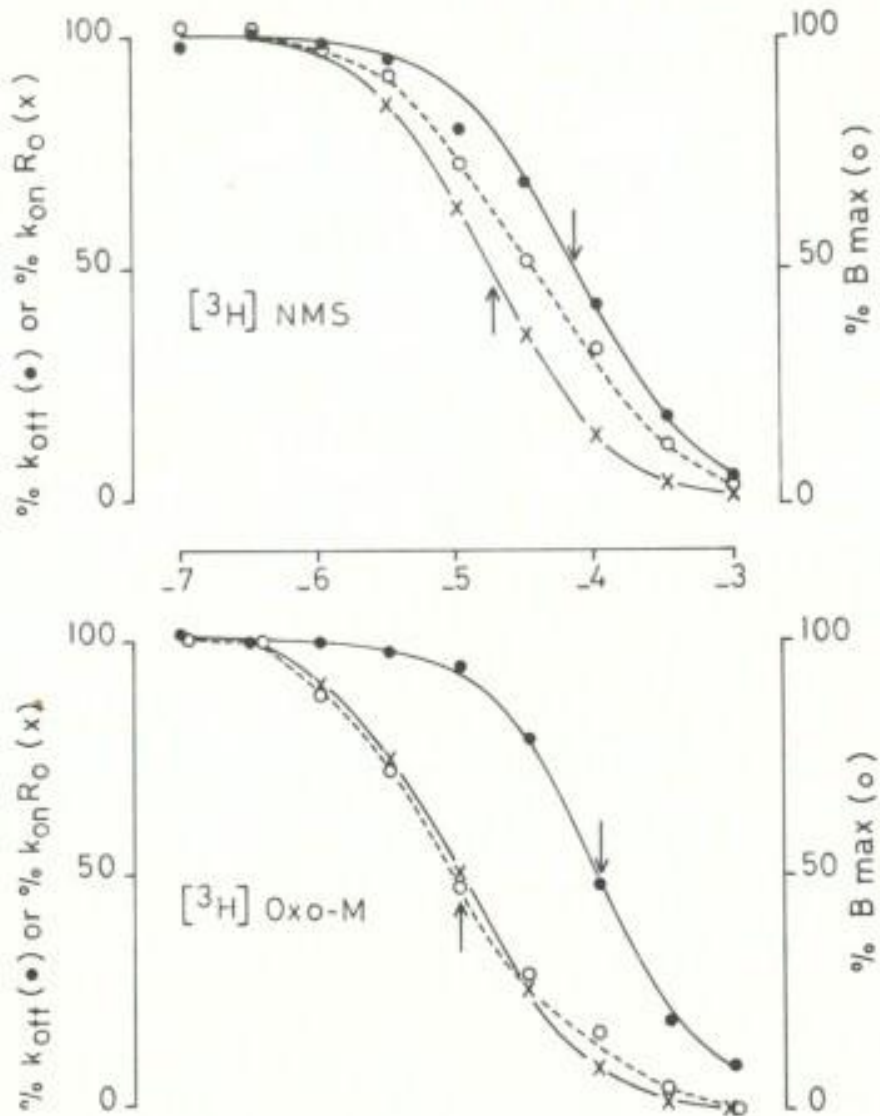

Effects of quinidine on the dissociation rate constant $(\bullet)$ and tracer binding after a 10 min incubation (0), using [3H] NMS (top) or [3H] oxo-M (bottom) as tracers (average of 2 to 6 experiments). The experimental data $(\bullet, 0)$ were fitted using equations 2 and 3 and the parameters shown in Table 1. In addition, tracer association rates $(X)$ in the presence of quinidine were calculated according to equations 3 and 4.

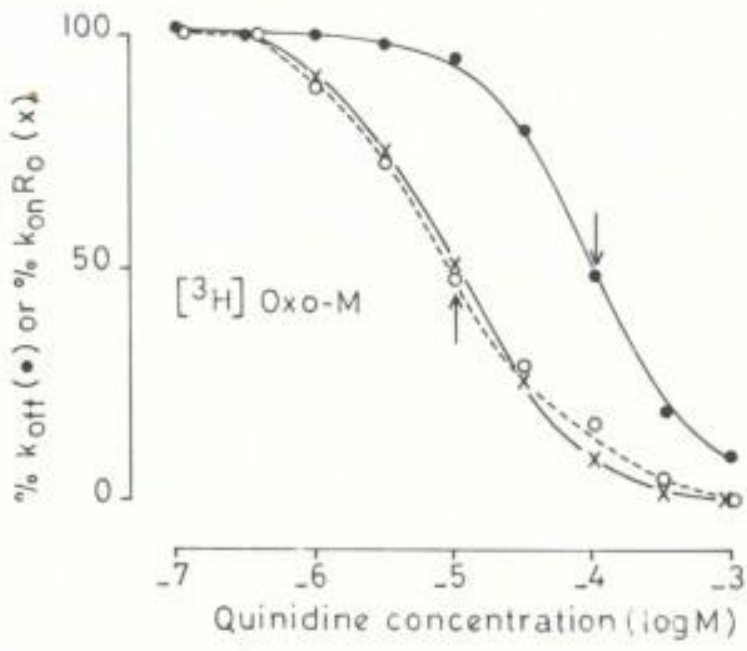

It is almost impossible to detect preferential binding to a receptor subclass by competition curves if the selectivity of the drug is too low and this is why one $K^{\prime} \mathrm{Q}$ value only was fitted to experimental data (Table I). However, the (small) difference between $\mathrm{K}_{0}^{\prime}$ values obtained with [ $\left.3 \mathrm{H}\right]$ NMS and $[3 \mathrm{H}]$ oxo-M might as well be due to preferential recognition by quinidine of the receptors with highest affinity for agonists. Indeed, an equally good fit of the [3H] NMS competition curves could be obtained assuming that about $40 \%$ of the total receptor population (i.e. the receptors labelled by [3H] $0 x_{0}-M$ ) had a $K^{\prime}{ }_{0}$ value of $4 \mathrm{\mu M}$, the remaining $60 \%$ ( $\mathrm{H}$ receptors) having a $\mathrm{K}_{\mathrm{Q}} \mathrm{H}_{\text {value }}$ of $10 \mathrm{MM}$. 

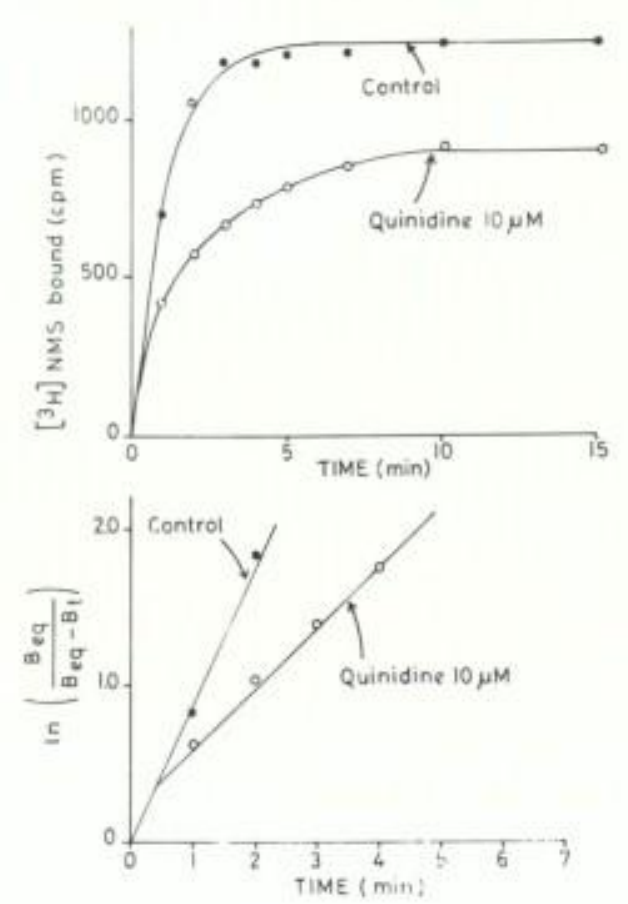

FIG. 5

The association of $\left[{ }^{3} \mathrm{H}\right]$ NMS to rat heart membranes was measured as a function of time in the absence $(\bullet)$ or presence (o) of $10 \mu \mathrm{M}$ quinidine (top). The results were analyzed according to equation (1) (bottom).

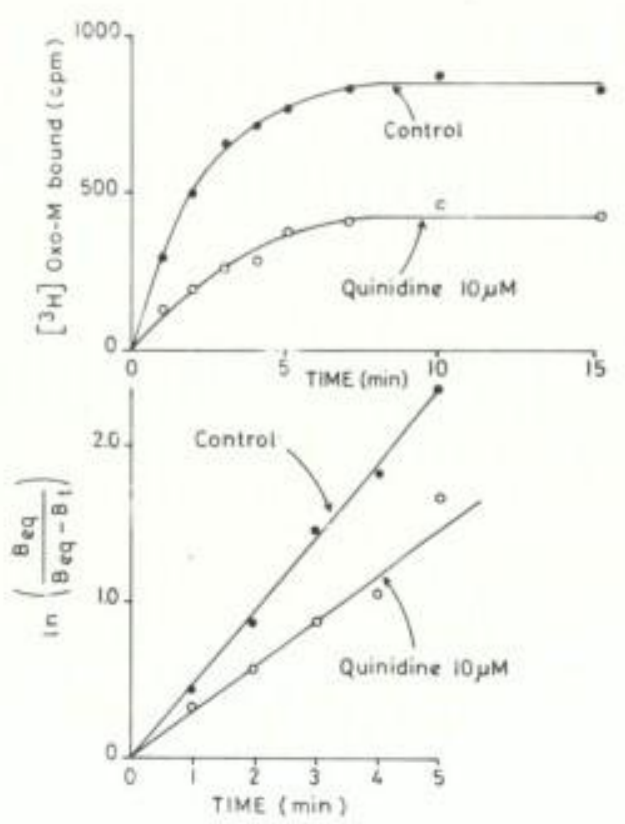

FIG. 6

Same as in fig. 5 , using $\left[{ }^{3} \mathrm{H}\right] \mathrm{O} \times \mathrm{O}-\mathrm{M}$ as tracer.

\section{Discussion}

The physiological consequences of the effects of quinidine described in this study are difficult to assess. The concentrations of quinidine used were partly in the toxic (above $10 \mu \mathrm{M}$ ) and partly in the therapeutic ( 1 to $10 \mu \mathrm{M}$ [2]) concentration range. Since "inhibitory" concentrations of quinidine depended on the ligand, receptor, and reaction examined (Table 2), it might well be that binding of agonists to the physiologically active state of muscarinic receptors could still be sensitive to quinidine when used at even lower concentrations.

In the present study, quinidine inhibited the binding of the muscarinic antagonist [3H] NMS in an apparently "competitive" manner (Fig. 1). It appeared to recognize the receptor subclass with highest affinity for agonists with a 2 -fold greater affinity than that of the average receptor population labelled by [3H] NMS. A detailed investigation of the kinetic properties of [3 3 ] NMS and $[3 \mathrm{H}]$ oxo-M in the absence and presence of quinidine indicated, however, that 
quinidine did not behave as a classical muscarinic agonist or antagonist. Interacting with a homogeneous, non cooperative class of "binding sites" (Hill coefficient of 1), quinidine was able to block the dissociation of both tracer-receptor complexes.

These effects could still be observed in the presence of the saturating concentration of atropine used when probing dissociation i.e. with all muscarinic binding sites occupied. We are therefore led to conclude that the inhibitory effects of quinidine on $[3 \mathrm{H}]$ NMS and $[3 \mathrm{H}] \mathrm{O} \times 0-\mathrm{M}$ dissociation rates were mediated by an accessory site distinct from muscarinic binding sites. At high quinidine concentrations, the $[3 \mathrm{H}]$ NMS and [3i] oxo-M dissociation rates decreases induced (small) increases of the tracer's affinities for their receptors. This compensated partially the competitive inhibition of tracers binding by quinidine. In this respect, quinidine behaves somewhat like gallamine and pancuronium $[12,13]$, inducing an apparent "receptor heterogeneity" by cooperative interactions with the muscarinic binding sites.

The decrease of the tracer's association rates (competitive inhibition) and dissociation rates (cooperative effects) might be due to quinidine interactions with the same accessory site. This site might, in fact, be located at the interface between receptors and membrane phospholipids when considering that quinidine exerts "cholesterol-1 ike" effects on acidic phospholipid bilayers [14].

\section{References}

1. C. CHASSAING, P. DUCHENE-MARULlaz and M. PAIRE. J. Pharm. Exp. Ther. 222. 688-693 (1982).

2. M.J. MIRRO, A.M. WATANABE and J.C. BAILEY. Circ. Res. 46, 660-668 (1980).

3. P. DUCOURET. Br. J. Pharmacol. 57, 163-184 (1976).

4. J.Z. FIELDS, W.R. ROESKE, E. MORKIN and H.I. YAMAMURA. J. Biol. Chem. $253,3251-3258(1978)$.

5. F.F. SNYDER and G.I. DRUMPOND. Arch. Biochem. Biophys. 185, 116-125 (1978).

6. M. WAELBROECK, P. ROBBERECHT, P. CHATELAIN and J. CHRISTOPHE. Mol. Pharmacol. 21, 581-588 (1982).

7. O.H. LOWRY, N.J. ROSEBROUGH, A.L. FARR and R.J. RANDALL. J. Biol. Chem. 193, 265-275 (1951).

8. A.M. TOLKOVSKY. Mol. Pharmacol. 22, 648-656 (1982).

9. Y. CHENG and W.H. PRUSOFF. Biochem. Pharmacol. 22, 3099-3108 (1973).

10. P. ARANYI. Biochim. Biophys. Acta $628,220-227$ (1980).

11. J. JARV, B. HEDLUND and T. BARTFAI- J. Biol. Chem. 255, 2649-2651 (1980).

12. J.M. STOCKTON, N.J.M. BIRDSALL and E.C. HUI.ME. Mol. Pharmacol. 23, 551-557 (1983).

13. J.. DUNLAP and J.H. BROWN. Mol. Pharmacol. 24, 15-22 (1983).

14. W.K. SUREWICZ. Biochim. Biophys. Acta $692, \frac{315}{315}-318$ (1982). 